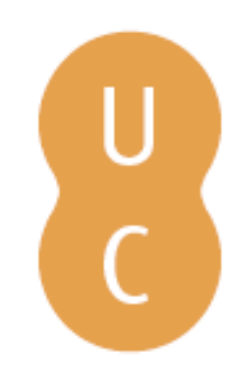

\title{
nommalina
}

\section{As águas que matam e as águas que salvam: a ambiguidade da água nos textos bíblicos}

\author{
Autor(es): $\quad$ Dias, Paula Barata \\ Publicado por: Imprensa da Universidade de Coimbra \\ URL \\ persistente: URI:http://hdl.handle.net/10316.2/45098 \\ DOI: $\quad$ DOI:https://doi.org/10.14195/978-989-26-1568-4_4 \\ Accessed : $\quad$ 26-Apr-2023 11:47:07
}

A navegação consulta e descarregamento dos títulos inseridos nas Bibliotecas Digitais UC Digitalis, UC Pombalina e UC Impactum, pressupõem a aceitação plena e sem reservas dos Termos e Condições de Uso destas Bibliotecas Digitais, disponíveis em https://digitalis.uc.pt/pt-pt/termos.

Conforme exposto nos referidos Termos e Condições de Uso, o descarregamento de títulos de acesso restrito requer uma licença válida de autorização devendo o utilizador aceder ao(s) documento(s) a partir de um endereço de IP da instituição detentora da supramencionada licença.

Ao utilizador é apenas permitido o descarregamento para uso pessoal, pelo que o emprego do(s) título(s) descarregado(s) para outro fim, designadamente comercial, carece de autorização do respetivo autor ou editor da obra.

Na medida em que todas as obras da UC Digitalis se encontram protegidas pelo Código do Direito de Autor e Direitos Conexos e demais legislação aplicável, toda a cópia, parcial ou total, deste documento, nos casos em que é legalmente admitida, deverá conter ou fazer-se acompanhar por este aviso.

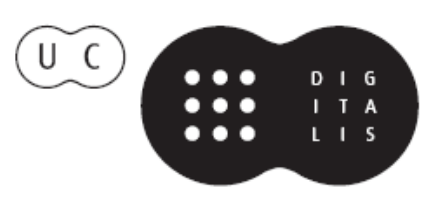




\section{O melhor é a água}

\section{Da antiguidade clássica aos}

nossos dias

José Luís Brandão \& Paula Barata Dias (coords.) 


\title{
As Águas QUE MATAM E AS ÁGUAS QUE SALVAM: A AMBIGUIDADE DA ÁGUA NOS TEXTOS BÍBLICOS (Waters That Kill and Waters That Save: The Ambiguity of Water In Biblical Texts)
}

\author{
Paula Barata Dias (pabadias@fl.uc.pt) \\ Centro de estudos Clássicos e Humanísticos ${ }^{1}$ \\ Universidade de Coimbra \\ orcid.org/0000-0002-4730-914X
}

\begin{abstract}
Resumo - A água apresenta, nos textos bíblicos, um estatuto ambíguo. A água que lava e a água que sacia são tópicos recorrentes na linguagem alegórica dos Evangelhos e no contexto objetivo de determinados episódios da vida de Jesus, a par de outros em que a mesma surge enquanto força aniquiladora. Analisando a presença e a simbologia da água em alguns episódios bíblicos, procuraremos interpretar o estatuto ambivalente das águas, (água de punição, água de salvação) à luz da construção tipológica enquanto hermenêutica cristã desenvolvida no NT a partir da ambivalência da água no AT.

Palavras-chave - água, Bíblia, Antigo Testamento, Novo Testamento, tipologia, prefiguração.
\end{abstract}

Aвstract - Water has an ambiguous status in biblical texts. Waters that wash and waters that quench are recurrent topics in the allegorical language of the Gospels and in the objective context of certain episodes of the life of Jesus, along with others in which it appears as an annihilating force. By analyzing the presence and symbolism of water in several biblical episodes, we will try to interpret the ambivalent status of water (water of punishment, water of salvation) in the light of the typological construction developed by Christian hermeneutics in the NT from the ambivalence of water in the OT.

Keywords - water, Bible, Old Testament, New Testament, typology, prefiguration.

Os episódios bíblicos associados à água fazem parte do nosso património de imagens, de referências simbólicas, poéticas e literárias, enquanto membros da cultura europeia e ocidental vincada nos eixos constituídos pela tradição grega, romana e judaico-cristã. Para a maior parte ainda, a água é elemento essencial válido em práticas rituais associadas a uma vivência religiosa cristã, (o batismo, e.g.), o que ultrapassa em muito o impacto da sua perceção enquanto mera

${ }^{1}$ Trabalho desenvolvido no âmbito do projeto UID/ELT/00196/2013, financiado pela FCT - Fundação para a Ciência e a Tecnologia. 
referência ou símbolo cultural ${ }^{2}$.

Como referências de uma história sagrada para o cristianismo, pertencem ao património comum as narrativas bíblicas em que a água é um elemento central, seja enquanto pano de fundo e contexto, seja enquanto fator de desencadeamento de determinados acontecimentos. O dilúvio, que destruiu a primeira criação, do qual escapou Noé e um par de cada uma das primitivas criaturas, no livro do Génesis; a travessia do Mar Vermelho a pé enxuto pelos Hebreus conduzidos por Moisés e afogamento dos exércitos do faraó, no livro do Êxodo; Jonas lançado ao Mar Mediterrâneo, do barco em que seguia para Ocidente, logo engolido por uma baleia, que o liberta na praia, três dias depois, para que cumpra a sua missão de partir para Nínive.

Integrados no mesmo género narrativo, mas já no NT, apresentam-se episódios de idêntica centralidade para a água: o batismo de Jesus no rio Jordão, num ponto inicial do Evangelho de Marcos que, não apresentando narrativa para o nascimento de Jesus, valoriza este episódio como uma espécie de segundo nascimento, o de Jesus enquanto Cristo "o ungido", no momento em que emerge das águas (Mc 1, 9). Após o batismo, e o recolhimento no deserto durante quarenta dias, Cristo "nasce" para a sua vida pública (Mc 1, 14).

Também os milagres e as maravilhas realizados por Jesus associados à água (As Bodas de Caná, com a transformação da água em vinho (Jo 2, 1-12); a "transferência para os porcos dos demónios que atormentam um possesso, que se despenham e se afogam no mar (Mc 5, 1-13, Mt 8, 28-34); as curas dos cegos e dos mudos, em que Jesus usa a sua saliva para fazer uma lama curativa (Mc 7, 35; Mc 8, 23); a restituição da visão ao cego de nascença que, após as palavras de Jesus, deve ir lavar-se na piscina de Siloé, contígua ao templo, para recuperar a visão (Jo 9, 6-12); o caminhar milagroso de Jesus sobre as águas; o apaziguamento das águas, em revolta por causa de uma tempestade súbita que se levanta e surpreende os navegantes (Jo 6 16-20; Mc 6, 45-52; Mt 22-33; Lc 22-25). Também nos é dito que Jesus, perseguido pelos Judeus, se retirou para a Transjordânia, atravessando o rio para além de onde João batizava (Jo 10, 40). Por fim, após a ressurreição, se repete no NT o motivo da pescaria abundante e miraculosa, na qual João, o discípulo predileto, reconheceu Jesus (Jo 21 6-7).

Estas ocorrências não são todas idênticas, nem têm o mesmo peso e eficácia nas narrativas, uma vez que a água pode ser agente, símbolo, mas pode, de modo neutral, servir de fundo enquanto contexto espacial. Tomemos o exemplo do episódio do despenhamento dos porcos no mar de Tiberíades após o exorcismo do possesso de Gerasa (Mc 5). Teria este passo uma leitura diferente se, em vez de afogados, se tivessem simplesmente despedaçado contra o solo? Pensemos

\footnotetext{
${ }^{2}$ Citamos os textos bíblicos na edição de Rahlfs 2004 para o AT; Nestle-Aland 1993 para o NT. Ocasionalmente, servimo-nos da Colunga-Turrado 1994. As traduções em português seguem a edição de Alves 2012.
} 
também na morte por afogamento dos exércitos do Faraó no Êxodo (Ex 15, 28). Alterar-se-ia a história, e o seu impacto posterior, se estes tivessem perecido, não por afogamento, mas por um tremor de terra, ou por um fogo de origem também divina? Até onde podemos limitar o que é cenário neutro e o que implica uma intencionalidade no uso de um determinado motivo? Neste domínio, pensamos que a sua recorrência e a existência de diálogo interno entre as manifestações podem servir de indicador de um uso para além do casual.

O motivo da água repetido em momentos significativos das narrativas, enquanto contexto, cenário primário da ação e enquanto assunto em si, organiza-se em dois eixos significativos, um negativo e outro positivo, ora de aniquilação ora de salvação (água que extermina; água que dá vida e salva), que são contrários entre si, mas que absorvem, na sua complexidade, a experiência da relação dos homens com a água enquanto elemento real. Além disso, o diálogo intratextual travado entre as várias referências à água manifesta que ela é deliberadamente portadora de significados que são pré-reconhecidos à composição e à criação dos textos, projetando como motivo literário as expectativas, as vivências, as experiências objetivas e quotidianas de quem criou os códigos para comunicar uma história e uma experiência espiritual.

\section{A água Na geografia do mundo bíblico}

A terra prometida para os Hebreus é escassa em água. Onde podemos fundamentar, pois, a motivação para a presença do motivo da água nos textos bíblicos? Recuperemos a experiência real da água para os homens que habitaram o espaço de composição dos livros da Bíblia ${ }^{3}$. Os lugares estratégicos da civilização hebraica situam-se no Médio-Oriente, na estreita faixa, de relevo irregular e de microclimas, com dominância para o clima mediterrânico, situada entre três grandes conjuntos de massas de água, duas bacias hidrográficas que acolheram os movimentos históricos de mobilidade dos Hebreus, de forma quase pendular: No norte de África oriental, o Nilo e o seu delta, a desaguar no Mar Mediterrâneo, logo seguido do Mar Vermelho, que separa o continente africano da Península do Sinai; os rios do Médio-Oriente Eufrates e Tigre, que hoje atravessam países como a Turquia, a Síria, o Iraque e o Irão e desaguam no Golfo Pérsico. Nas suas margens, e graças às dádivas proporcionadas pela abundância de água, civilizações poderosas, com milénios de história, emergiram e condicionaram o espaço geográfico intermédio, influenciando não só a história como também a visão do mundo, a memória, a transmissão do conhecimento oral e escrito. Entre estas duas extensas bacias hidrográficas, o vale do Jordão, do Orontes e do Litani (atravessando os territórios dos atuais Jordânia, Israel, Síria e Líbano), e ainda a planície de Israel e as fossas em torno do Mar Morto, serviam

\footnotetext{
${ }^{3}$ Wright 194. Isbouts 2007.
} 
de canais de comunicação e de circulação de povos. As terras de Canaã, (para nos cingirmos ao espaço histórico e mítico identificado como a terra prometida aos trânsfugas do Egito), são territórios excêntricos em relação aos grandes rios e às maravilhas por eles proporcionadas, mas que acolheram povos que se moviam entre estes dois grandes vales fluviais, registando o AT episódios históricos que documentam a migração para o Egito ou o exílio na Babilónia.

Assim, o Tigre e o Eufrates irrigavam o Jardim no Éden (Gen 2, 14). Abraão migrou de Ur, cidade dos baixios aluviais do rio Eufrates (Gen 11, 31), para a região de Canaã. José, filho de Jacob, fixou a sua descendência no Egito, terra para onde fora vendido, mas que depois se tornou, durante gerações, lar de acolhimento dos Hebreus fugidos de uma grande fome (Gen 42, 1-2; emigração de Jacob para o Egito (Gen 46). A memória escrita dos Hebreus corrobora pois este movimento migratório algo pendular entre os grandes rios a este e a sudoeste de Israel, como fazendo parte de circunstâncias diversas e não necessariamente más.

O contacto com os territórios destes grandes rios refletiu-se, todavia, numa leitura traumática. O exílio do povo Judeu, na Babilónia de Nabucodonosor (597-587 a.C.) foi uma experiência histórica que marcou o fim da primeira existência enquanto espaço-nação e o desmoronar das suas referências fundamentais. Este exílio ficou de tal modo impresso na experiência dos Judeus que nesse momento e lugar se situaram os inícios da fixação da história formal de Israel, ocorrendo a ordenação escrita dos testemunhos orais acerca de um passado mítico, histórico e religioso, e também a reinterpretação deste à luz das experiências transformadoras das viagens e do exílio recentes. O Génesis e o Êxodo fixaram-se literariamente durante ou após o cativeiro, na alvorada da construção do $2^{\circ}$ templo (587-538). Só nesta fase o Pentateuco verá a sua forma definitiva, a partir de uma geração que conhecera a experiência do exílio. Assim, é sobre os rios da Babilónia que os Judeus se sentam a chorar com saudades de Sião, e juram não esquecer Jerusalém (S1 137).

Nesta fixação da memória se inscreve a racionalização da experiência migratória no Egito que serve de pano de fundo ao Exxodo. O cativeiro dos descendentes de José no Egito e a sua libertação pelo fundador Moisés, acontecimentos anteriores ao primeiro milénio, anteriores a outros tão importantes para a identidade política do estado de Israel, como são a conquista de Canaã por Josué, a formação das doze tribos de Israel, a fundação de Jerusalém, a edificação do templo, só viram a redação definitiva acontecer após o séc. VI, durante ou logo após o exílio babilónico, surgindo esta experiência contaminada pela memória de um primeiro exílio. Momentos históricos e gerações distintas experimentaram portanto os "rios dos outros", inscrevendo estes encontros e desencontros na perceção de paisagem interpretada como estranha e estrangeira, em que memória de um passado mítico e uma história traumática se encontram, 


\section{convergem e se contaminam.}

Se os acontecimentos narrados no Êxodo são problemáticos do ponto de vista da objetividade histórica, o tratamento pela memória coletiva das origens míticas do povo de Israel e da legitimidade da sua aspiração ao solo de Canaã, tal como transparecem do Exxodo e dos livros dos Reis, tal como a redação dos primeiros livros da Bíblia Judaica, surgem objetivamente marcados pela experiência histórica do exílio babilónico, o tempo da fixação escrita dos textos identitários para os Judeus. A memória dos compositores dos textos bíblicos está, assim, condicionada por uma avaliação do espaço e da geografia estrangeiras distinta e diferenciada da que concebe como pátria e ponto de partida ideal. $\mathrm{Ou}$ seja, a paisagem natural e humana dos outros, os seus elementos dominantes, as suas características e traços distintivos serviram enquanto símbolos de culturas hostis, opostas ou distintas ${ }^{4}$.

A terceira paisagem aquática presente nas histórias da Bíblia, ainda que com menor expressão, é o Mediterrâneo ${ }^{5}$. As viagens marítimas a partir da costa são esporádicas. Está presente no episódio de Jonas, livro de pequeníssima extensão, porém fundamental para o tema aqui tratado. Composto também após o cativeiro, ficou na imaginação popular a história deste profeta, que resistiu à missão de que Deus o investiu e embarcou para Társis, no Ocidente. No Mediterrâneo, uma terrível tempestade ameaça fazer naufragar a embarcação (Jn 1, 4-5), e os marinheiros recebem o vaticínio de que Jonas é o causador da fúria divina. Lançado ao mar, é engolido por uma criatura marinha que, após três dias, o larga intacto na praia (Jn 2,11). O profeta cumpriu, a contragosto, a sua missão de converter Nínive, poupando a grande cidade à destruição. Também o incansável Paulo, já no NT, embarcou de Selêucia para Chipre na primeira viagem missionária (Act 13, 6). A partir da Tróade, navegou para a Samotrácia e Macedónia, momento que marcou a chegada do cristianismo ao continente europeu (Act 16, 11). De maior fôlego, a viagem do prisioneiro Paulo a caminho de Roma, acidentada e perigosa, com transbordos, tempestades, deriva no mar, naufrágio e a salvação

${ }^{4}$ Em Dias 2010: 147 - 163, analisámos as referências concretas e simbólicas ao peixe na Bíblia. Estamos convencidos de que a perceção de se habitar uma geografia e de uma natureza distintas das que eram identificadas como pátria está na génese da separação entre espécies de peixe aceitáveis e espécies interditas para a alimentação humana, e que esta inferência pode ser aplicada a grande parte dos interditos alimentares do Levítico e do Deuteronómio. São rejeitados os peixes de águas paradas e de pântano, isto é, sem escamas (vs. peixe de água corrente).

${ }^{5}$ Ramos 1998: 14-17 defende que a interferência dos "mares" na vida quotidiana da sociedade hebraica era pouco significativa, designasse o termo o Mar Mediterrâneo, as águas salgadas; designasse os lagos internos, de água doce, indistintamente chamados de "mar" (yam em Hebraico; ver, a propósito desta "indistinção", Ramos 2008: 62), "não parece ser da experiência marítima acumulada pelos Hebreus que se forjou a densidade simbólica e mitológica com que a imagem do mar se encontra valorizada na literatura bíblica”. 
nas costas de Malta (Act 27) . O Mediterrâneo do séc. I fornecia condições de mobilidade mais acessíveis do que no tempo de Jonas, o que é confirmado pela referência aos barcos que, de vários portos, mas especialmente de Alexandria, faziam carreira pelos portos do Mediterrâneo oriental (Act 27, 6; 28, 11).

Mas o Mediterrâneo constituía sempre um perigo, estando a sua perceção refletida no relato de Jonas e nas viagens de Paulo com a referência a tempestades de carácter sobrenatural, cujo apaziguamento reclama a intervenção mágico-religiosa dos viajantes. A pesca na Bíblia é uma atividade de água doce, de rios e de lagos. O mar só é mencionado nos casos referidos: por razões de viagem, e no Apocalipse, integrado nas visões de Paulo em Patmos. Os seres que nele vivem não têm interesse económico, constituem ameaças ou monstros, como vemos na cena de Jonas ou em Apocalipse 13, 1, em que um dragão emerge do mar. Os homens na Bíblia movem-se e migram por terra, mesmo que as ondas se desviem para poderem passar incólumes, como no Exodo (Ex 14, 21). É portanto compreensível que a Bíblia se reencontre com o Mediterrâneo precisamente nos Actos, nas Epístolas e no Apocalipse: são estes os textos que mais diretamente refletem o contexto histórico político do mundo de Jesus, com o Império Romano, assente todo ele na estabilidade deste lago romano que foi o Mediterrâneo no Alto Império.

Numa escala mais local, o clima e a orografia do litoral de Israel e dos territórios costeiros do Próximo Oriente são tipicamente mediterrânicos: paisagem de relevo acidentado, com pequenos cursos de água ditos "de cachão", em que um declive acentuado associado a uma pluviosidade irregular, que brotavam abundantes no outono e inverno mas que diminuíam nas estações quentes, tornava preciosa a imagem de um ribeiro de águas correntes. Daí a importância, desde tempos milenares, das captações subterrâneas de água, poços ou cisternas, ou mesmo um oásis, que amenizavam uma paisagem semiárida. Podemos, certamente, intuir a alegria resultante de uma visão tão agradável como a de pontos estratégicos de água potável, isolados numa paisagem seca, vitais para homens e fauna (cf. S1 41 “como suspira o veado pelas águas vivas...").

Do ponto de vista instrumental, a água dessedenta, lava e limpa, repondo a pureza física e a ritual. Assim, o Levítico estabelece regras claras quanto à ablução das mãos, limpeza corporal, lavagem da roupa e dos utensílios usados para a alimentação ${ }^{7}$. Estas qualidades da água são vistas como objetivamente

\footnotetext{
${ }^{6}$ Dias 2011: 45-53.
}

${ }^{7}$ Em Lev 13, 6, se um homem tiver uma afeção benigna da pele, lavará as roupas e ficará puro; Lev 13, 53, a roupa atingida pela lepra corrosiva, se esta não alastrar, lave-se a parte manchada. Lev 14, dedicada à purificação dos leprosos pela aspersão do sacerdote, pelo banho. Em Lev 15, a impureza circunstancial de homens e de mulheres contamina os objetos, utensílios e pessoas em que eles tocam. A pureza recupera-se com a lavagem dos objetos, das roupas e o banho para as pessoas. 
boas, participando na alimentação, na higiene e saúde dos que dela se servem. A água que lava concretamente está presente enquanto metáfora de limpeza no ritual do batismo tal como ele surge narrado nos Evangelhos, como veremos. E “o rio de água viva" é o primeiro referente da última visão escatológica do Apocalipse de João, que emana do trono de Deus e do cordeiro, em cujas margens está a árvore da vida, com frutos que alimentam e curam os justos que ficarão com o Senhor. O mesmo livro conclui-se com a exortação dirigida ao "que tem sede: que se aproxime e que beba da água da vida ${ }^{8}$

Percebida como bem precioso, a experiência concreta dos homens quanto ao uso da água manifesta-se pela vontade de controlar este recurso, poços, cisternas, águas represadas. Por exemplo, Lot estabelecera-se na planície do Jordão, por esta ser irrigada (Gen 13, 10). Noutro episódio do Génesis, surge-nos o conflito entre Isaac e o Filisteu Abimelec, em que este exprime a sua hostilidade enchendo de terra os poços abertos por Abraão (Gen 26, 15-25). Isaac abriu mais poços, que levantavam novos conflitos pela posse da terra entre comunidades de agricultores e de pastores. Ter um poço era condição para o sedentarismo, possuir a terra, dar-lhe um nome, reclamá-la para si. E por isso, neste episódio é tão relevante a associação entre o encontrar água e o dar o nome ao poço, numa repetição do ato primordial da criação em que o ser nomeado em voz alta é tão ou mais significativo para a existência do que nascer (Gen 2, 20; Is 8, 8; Mt 1, 23; Mt 4, 17; Mc 1, 11; Lc 1, 60; Mt 16)9.

Esta experiência da água preciosa e escassa que caracteriza a terra-mãe, fonte de vida, distingue-se completamente da que descrevemos como a experiência da "água dos outros" em terra estrangeira, Egito e Mesopotâmia, com vastas planuras inundadas de grandes rios que desaguam em deltas, rodeados de terrenos de grande fertilidade.

Os espaços naturais em que se desenrolaram as narrativas bíblicas e a experiência concreta das águas, sua observação, utilização, contingências constituíram-se referências concretas de construção de discurso, mas também de avaliação e de metaforização para realidades menos concretas como são as da significação religiosa. Se aceitarmos que as experiências, a mobilidade e a observação se transformam em memória e cultura dos povos, entenderemos que o discurso bíblico acerca das águas não é unívoco nem uniforme, mas antes complexo, matizado, e mesmo ambivalente, no sentido em que o mesmo episódio pode comportar as duas leituras, positiva e negativa, acompanhando a variedade de experiências históricas dos homens seus autores.

\footnotetext{
${ }^{8}$ Apoc 22 1-3; 17.

9 Ramos 2008: 64-65, acerca da importância do ato de nomear nas narrativas humanas acerca da criação "nomear as coisas é, portanto, defini-las [...] este gesto projeta-se coletivamente por sobre a história da humanidade, com todo o aspeto da criação de uma convenção. Ordenar e definir é uma imagem do processo histórico da vida dos humanos”.
} 
Vejam-se dois casos concretos desta ambivalência no aproveitamento da “água dos outros" para as narrativas bíblicas. A dádiva de vida que é o Nilo para os povos que se fixaram nas suas margens é perfeitamente tida em conta no Exodo, porque a primeira praga enviada pelo deus dos Hebreus o fere diretamente: as suas águas, o coração da vida dos egípcios, convertem-se em sangue, deixando-a imprópria e envenenando os peixes, o que leva os egípcios a procurar águas subterrâneas (Ex 7, 19-25). De fonte de vida, o Nilo se torna espaço de morte. Também a experiência do imprevisível poder das águas, criadoras de vida e aniquiladoras, era ciclicamente sentida pelos povos da Mesopotâmia. A precipitação sobre as suas nascentes, nas montanhas do Cáucaso, provocava imprevisíveis e destruidoras inundações que acabavam em imensos pântanos, sob o golfo Pérsico. O dilúvio que aniquilou a primeira criação de Deus, no Génesis, compôs-se a partir desta experiência das águas que sobem, após chuvas ininterruptas, trazendo com elas a aniquilação cíclica ou sazonal, mas proporcionando um recomeço, ou uma refundação de um mundo que se regenera ${ }^{10}$.

Nestes termos, os da complexidade da constituição das memórias em contexto de mobilidade e de exílio e os da diversidade das experiências de contacto com as águas, se podem pois encontrar as motivações para a riqueza e a ambivalência significativa da água nas narrativas bíblicas, vista como força negativa e força positiva.

2. A tipologia da água aniquiladora e salvadora. A viagem e a PERMANÊNCIA Do SÍMBolo ENTRE O AT E O NT

A tipologia da água constitui uma chave hermenêutica válida para a leitura literária da Bíblia, para a compreensão da persistência do seu valor ambivalente até aos cristãos e, sobretudo, para entender a permanência e a revisitação da simbologia da água simultaneamente aniquiladora e salvadora na composição dos textos neotestamentários. Trata-se de um assunto que apresenta já uma ampla e consagrada bibliografia. Iremos focar-nos na específica leitura do que neste assunto constitui um caso muito interessante de ambivalência, ou de paradoxo: a água enquanto elemento negativo, primordial, estranha para os homens e até anterior a Deus, elemento que põe à prova e proporciona a alguns a salvação ${ }^{11}$.

Vamos fixar-nos no valor tipológico da água, no sentido que a expressão

${ }^{10}$ É incerto se o dilúvio da Bíblia elabora sobre a memória de uma inundação episódica e destruidora, ou sobre uma experiência, diríamos crónica, de um fenómeno cíclico. O tema está presente em várias culturas, mas não é seguro se tal se deve à partilha das mesmas fontes mítico-literárias se há elaboração independente da memória de um cataclismo mais universal. (Cf. o mito de Deucalião, filho de Prometeu, e de Pirra, o casal que escapa ao dilúvio que põe fim à raça humana, por ordem de Zeus) Os dois, o mito de Noé e o mito de Deucalião, aproximam-se da epopeia de Gilgamesh. Note-se, contudo, que o motivo do dilúvio pode resultar de um acrescento tardio (Tigay 1982. Lambert y Millard 1999.

${ }^{11}$ Acerca do "mar" enquanto figuração do elemento arquetípico da água, ver Ramos 1998: 
"tipologia" apresenta para a hermenêutica literária do texto bíblico ${ }^{12}$ : sendo este uma biblioteca de livros compostos em tempos, lugares, autores, assuntos e géneros literários distintos, cada compositor se coloca em diálogo e reação com a tradição anterior, criando eixos de sentido que têm como referentes episódios para além do estritamente narrado, mas válido, enquanto sistema de símbolos para o conjunto de textos em relação. Esta harmonia é particularmente visada na interpretação das relações entre o AT e o NT, em que os episódios dos tempos anteriores à revelação de Cristo foram interpretados enquanto prefigurações, símbolos ou anúncios do que viria a cumprir-se no NT.

Esta leitura e de interpretação dos textos sagrados da tradição matricial judaica foram conduzidas pelas primeiras gerações cristãs, empenhadas em ancorar a sua identidade nos textos sagrados judaicos, na tradição e cultura religiosa de que emergiram e assim, incorporar a revelação cristã na única Bíblia que conheciam, o Antigo Testamento. Este exercício hermenêutico de que os primeiros compositores dos textos do NT foram capazes exigia delicados compromissos, no sentido de preservar a comunicação com a matriz judaica, nuclear e apresentada como prefigurativa da revelação cristã e o seguimento lógico do compromisso entre Deus e o povo eleito firmado no AT. Esta exegese operou-se com grande frequência na primeira literatura patrística, mas é na composição dos textos do NT que encontramos os sinais desta reação e diálogo com um património literário anterior e recebido como fundador.

A diversidade de autores e de géneros literários no NT debate-se, em primeiro lugar, com um problema: existe um património e uma experiência religiosa matricial, literariamente estabilizada, constituídos pelos textos sagrados das comunidades judaicas do séc. I e II, e existe uma história alusiva a um curto episódio de três anos (a experiência histórica da vida de Jesus), fundada em eventos testemunhados, transmitidos oralmente dos apóstolos para os seus sucessores. Há um hiato temporal entre a vida e morte de Cristo e a composição dos textos especificamente alusivos à nova fé, o NT em que se reflete, se medita, e se elabora o discurso acerca do significado da figura de Jesus. Como é sabido,

19; Ramos 2008: 64.

${ }^{12}$ Um bom resumo sobre a teoria literária da tipologia encontra-se em Martens 2008: 283-317. Deixamos duas definições de "tipologia”: em Daniélou 1951: 199 "The object of typology is the research of the correspondences between the events, the institutions, and the persons of the Old Testament and those of the New Testament, which is inaugurated by the coming of Christ and will be consummated with his parousia." Em Hanson 2002: 7, a distinção entre tipologia e alegoria, a primeira como um evento, a segunda como um objeto, ou personagem: "Typology is the interpreting of an event belonging to the present or the recent past as the fulfillment of a similar situation recorded or prophesied in Scripture. Allegory is the interpretation of an object or person or a number of objects or persons as in reality meaning some object or person of a later time, with no attempt made to trace a relationship of "similar situation" between them". 
os primeiros textos neotestamentários a serem compostos eram de natureza pastoral, catequética, e não narrativa. Neles se encontra o esforço de adequação, ou de compreensão da revelação de Cristo à luz de uma cultura e de narrativas religiosas prévias, as do ponto de partida dos autores. As cartas de Paulo pressupõem o conhecimento de uma história nova que foi recebida através de múltiplos relatos orais, que complementavam ou teriam de se articular, enquanto elementos de uma experiência religiosa nova, à leitura e meditação dos textos consagrados pela tradição e culturas religiosas judaicas, ou seja, os textos do AT. Assim, a redação paulina está repleta de momentos em que este diálogo emerge. E quando a narrativa dos novos eventos foi adquirindo forma e se foi compondo na escrita, apresentada como a Boa Nova (os Evangelhos), surge já condicionada por este diálogo com a tradição veterotestamentária, conhecida e manuseada pelas primeiras gerações que aderiram a Cristo, os mesmos que continuavam a reunir-se nas sinagogas e a respeitar os princípios da religião dos seus antepassados. Assim, entre as narrativas dos Evangelhos e o AT o movimento é todo vertical, analéptico ou proléptico, conforme o foco em que nos colocamos ${ }^{13}$. São os episódios do AT prefigurações da revelação de Cristo; são os episódios dos Evangelhos realizações, ou configurações do AT. O NT está repleto dos incisos "segundo as escrituras"; "para que se cumprissem as escrituras"; há passos que recordam ao destinatário que lhe está a ser revelado um conhecimento e uma realidade prenunciada, de modo por vezes hermético, mas cuja chave lhe foi escancarada com a revelação de Cristo. Estabeleceram-se deliberadamente nexos de sentido, intertextos mais ou menos explícitos, suficientemente coesos para que se levante a cautela de não ler os Evangelhos como uma narrativa objetiva, na medida em que se sobrelevam os pontos de contato, e se lançam na sombra ou se omitem os pontos excêntricos a uma tradição cultural prévia ${ }^{14}$.

A análise do significado ambivalente da água nos textos bíblicos assume estes pressupostos teóricos, considerando-a como um dos motivos cuja inteligibilidade e coerência pressupõem o diálogo vertical das suas ocorrências e manifestações. Trata-se de um assunto com uma ampla bibliografia de que destacamos alguns títulos no final, e que nos serviram para iluminar o paradoxo relativo à água enquanto acompanhamos o texto bíblico: elemento amigável, portador e dador de vida e simultaneamente elemento negativo, de estranheza e de provação.

${ }^{13}$ Veja-se um exemplo significativo, neste caso concreto alusivo à experiência da água enquanto lugar de abismo e de provação, em Mt 12, 38. Cristo vitupera os que reclamam pelo sentido (a referida ânsia em enquadrar a figura de Jesus na experiência religiosa de base) com as palavras: "Geração má e adúltera! Reclama um sinal, mas não lhe será dado outro sinal a não ser o do profeta Jonas. Assim como Jonas esteve no ventre do Cetáceo três dias e três noites, assim o filho do homem estará no seio da terra três dias e três noites". Ou seja: só lhes será dada a coincidência, a similitude entre o acontecido com Jonas, e o que virá a acontecer com Jesus. Esta coincidência é o sinal da inteligibilidade do plano de Deus.

${ }^{14}$ Daniélou 1950; Goppelt 1982. 
No relato da criação, no Génesis, o espírito de Deus "sustem-se" (epipheresthai) sobre as águas, que Deus não fez (poeisthai) nem nomeou (kaleisthai), termos estes que nunca se aplicam à água, que não é uma criatura como as outras $(\text { to bydor })^{15}$. Em relação à água, no relato da criação cósmica, Deus parece pôr em ordem uma substância que pré-existe, atribuindo-lhe duas geografias precisas. Separando-as (diachorizein) através de um firmamento, (stereoma) ordenou primeiro as que estavam sob este firmamento (bypokato tou stereomatos) ${ }^{16}$. Ainda no segundo dia, reuniu (sunagesthai) as águas da terra num só lugar, a fim de que aparecesse a terra seca (xera). À parte seca chamou terra ( $g e$ ), à parte húmida chamou de mar (thalassa $)^{17}$. No quinto dia da criação, Deus ordena que as águas sejam povoadas (exagesthai) de seres vivos (ta herpeta hydata psychon zwoson), fazendo (poieisthai) os grandes monstros marinhos (ta kete ta megala) e todos os seres que povoam (exagein) as águas. É também neste dia que Deus cria as aves aladas, que voam "sob o firmamento dos céus" (kata to stereoma tou ouranou). Ou seja, estes dois lugares, "sob o firmamento" e as águas da terra, paralelamente, povoam-se de vida no mesmo ato de criação ${ }^{18}$.

Pela água foi aniquilada a quase totalidade da primeira criação. No episódio de Noé, sobreviveram os pares de cada ser vivo terrestre, quadrúpede, rastejante e aéreo criado, sendo, portanto, concedida a esta semente a possibilidade de iniciar uma segunda criação $(\mathrm{Gen}$ 6, 20). Pouco surpreendente será perceber-se que os seres aquáticos não tiveram lugar na Arca. De facto, esta extinção maciça da vida não os afetou, pois a água era o seu habitat natural ${ }^{19}$.

Será útil também observar o modo como Deus desencadeia o dilúvio,

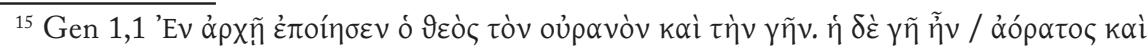

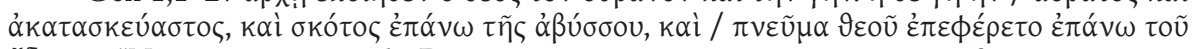

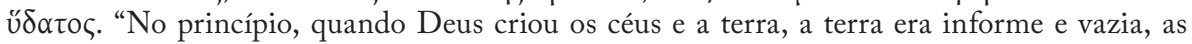
trevas cobriam estava o abismo e o espírito de Deus movia-se sobre a superfície das águas".

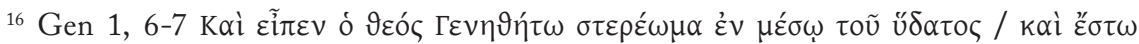

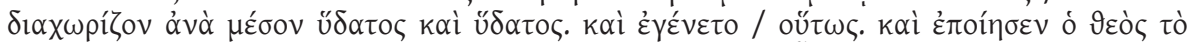

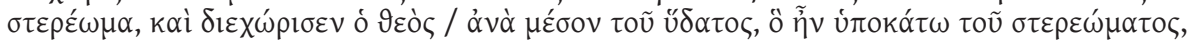
“... Deus disse: " haja um firmamento entre as águas para as manter separadas umas das outras”. E assim aconteceu. Deus fez o firmamento e separou as águas que estavam sob o firmamento das que estavam por cima do firmamento.” O relato da criação, a ordenação das águas em subterrâneas e aéreas e a ausência de categorização específica para as águas salgadas (ou seja, o mar) na Bíblia é de influência suméria (Ramos 2008: 61-62).

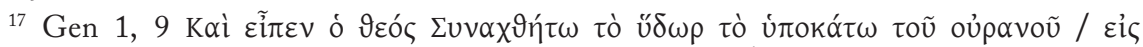

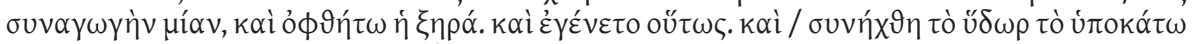

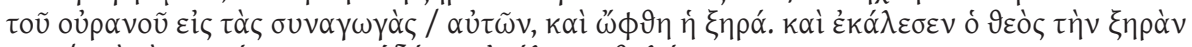

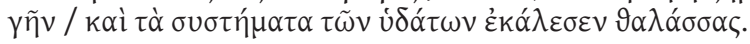

${ }^{18}$ Gen 1, 20, 21. Dias 2015: 132-135.

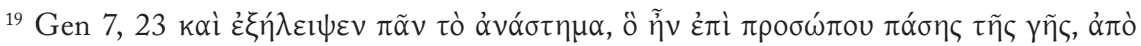

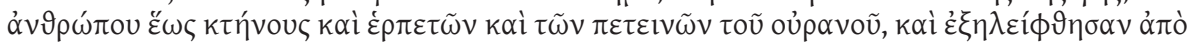
$\tau \tilde{\eta} \varsigma \gamma \tilde{\eta} \varsigma$. "Foram assim exterminados todos os seres que se encontravam à superfície da terra, desde os homens até aos quadrúpedes, aos répteis e aves dos céus.” 
restaurando-se, neste processo, a unidade primordial das águas, antes de terem sido colocadas sob o firmamento e separadas da terra seca. Assim, rompem-se as fontes do abismo e abrem-se as cataratas do céu ${ }^{20}$ : De modo inverso se retoma a separação entre as águas superiores (a chuva) das águas inferiores (a água sobre a terra) quando o dilúvio cessa: Deus envia um vento sobre a terra, análogo ao sopro de vida com que insuflara a primeira criação, as fontes e as cataratas do céu são fechadas (koptein, kalyptein) e a chuva parou de cair do céu (sunechesthai) ${ }^{21}$. Assim, a descrição do episódio do dilúvio revive o momento confuso anterior à criação, em que as águas se encontravam à solta, e em desordem. Deus tem o poder de domesticar as águas, no sentido em que as retém no firmamento, desencadeando as chuvas, e prende-as nas nascentes, soltando os rios, como the aprouver. Tal como a criação da vida só teve lugar após o aparecimento da "terra seca” separada das águas, e a arrumação (classificação?) destas nas categorias espaciais de "águas superiores" e "águas inferiores", a destruição da vida recupera, no movimento inverso, a união destas categorias. Contudo, não nos parece demais vincar dois aspetos essenciais à nossa demonstração acerca do controverso valor das águas nos textos bíblicos: não só o elemento aquático não é uma criatura de Deus, no sentido em que, pelo menos lhe coexiste e Deus tem sobre ele um poder de "organizador"; os seres que nele habitam, sendo criaturas de Deus, não foram aniquilados com o dilúvio, resultando portanto da primeira criação.

Tal como se repete, no dilúvio, a cosmogonia da primeira criação, também a tipologia de espécies selecionadas para a arca recupera o ordenamento da biologia da primeira criação, com o acrescento do critério da "pureza", neste ponto do discurso claramente anacrónico: são sete pares de todos animais puros e um par de todos os animais impuros. São salvos casais de quadrúpedes de répteis e de aves "segundo as suas espécies" (kata to genos). Esta fórmula, recorrente na criação da vida animal no Gen 1, 21-25, assim como a classificação das mesmas segundo a tipologia quadrúpedes, répteis e aves aparece novamente no catálogo dos animais que entraram na arca em Gen 6, 14-15. A segunda criação revive, portanto, a primeira criação, com a exceção de esta segunda criação omitir o destino dos seres aquáticos, que podem sobreviver no seu ambiente natural. Esta natureza pré-diluviana dos seres marinhos terá reflexos em vários episódios do AT e do NT.

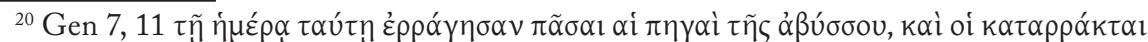

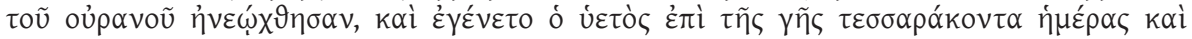

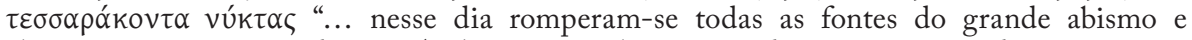
abriram-se as cataratas do céu. A chuva caiu sobre a terra durante quarenta dias e quarenta noites."

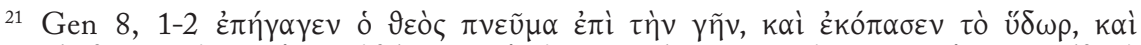

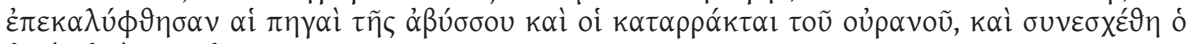

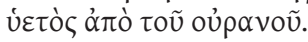


O destino das aves também merece nota para perceber a dimensão do dilúvio como um fenómeno que, tal como é descrito, recupera a confusão de elementos iniciais, incompatíveis com a vida. O facto de estarem incluídas entre as espécies acolhidas na arca permite-nos interpretar o dilúvio como um episódio de reunião integral das águas do céu e da terra, a ponto de não permitir aos seres alados voar, como se o elemento aéreo tivesse sido engolido. Na verdade, o que nós temos é o dilúvio absoluto que resulta da “junção das águas" do céu e da terra separadas aquando da criação que ocupa a atmosfera, ou o intervalo de ar entre a terra e a abóbada celeste, lugares de "contenção" das águas por vontade divina. Assim, não há ar para as espécies aladas voarem, e por isso têm de ser salvas. Só quarenta dias depois de começarem a emergir os cumes das montanhas (ou seja, cessadas as chuvas se restabelece após quarenta dias uma "almofada de ar"), Noé solta um corvo, depois uma pomba em busca de terra seca (Gen 8 6-12). Eles vão retornando, porque não encontram lugar seguro para poisar. Estes seres são os únicos capazes de se movimentarem (mas não de sobreviverem sem apoio da arca) no espaço aéreo intermédio, que cresceu apenas após os quarenta dias de submersão, depois de as águas começarem a baixar e se fecharem as chuvas do céu.

A família de Noé saiu ilesa do ventre da arca, tal como ileso sairá Moisés do afogamento a que estava destinado e que acontecia aos meninos hebreus no Egito do cativeiro (Gen 1, 22), boiando num cesto também impermeabilizado por betume como a arca de Noé22 ... tal como Jonas sobreviverá no ventre do ketos, o monstro marinho que o engolira quando foi jogado ao mar e o salvou do afogamento. A narrativa dos acontecimentos em Jonas é extraordinariamente ambígua pois, ao ser lançado borda fora, hesita-se em considerar se Jonas é engolido como uma presa por um predador (interpretação mais frequente: o "inimigo" de Jonas é o monstro marinho), ou efetivamente salvo do afogamento por este ser, que o conserva três dias sem o digerir, e o lança incólume na praia. Contra a previsibilidade da imagem do homem caçado como uma presa, na verdade, o ketos funciona como uma "arca" que o protege da hostilidade das águas.

No interior do monstro, Jonas exprime a angústia de um homem submergido, engolido sob as águas, mas vivo, que experimentou o terror de estar encerrado na morada dos mortos. Também o abandono de Jonas no interior das águas exprime o retorno ao abismo primordial, em que o líquido e o sólido retomam a sua unidade ou confusão inicial: desordem e profundidade (o abismo, o seio

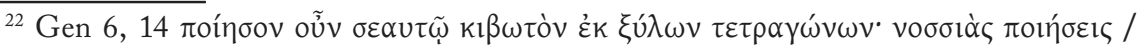

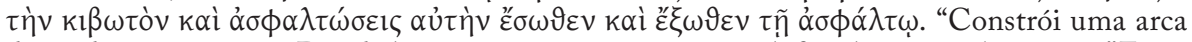
de madeiras resinosas. Dividi-la-ás em compartimentos e calafetá-la-ás com betume...”Ex 2,

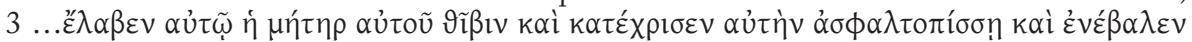

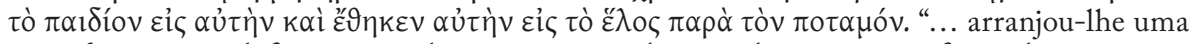
cesta de papiro, calafetou-a com betume e pez, colocou nela o menino e foi pô-la nos juncos da margem do rio." 
dos mares, as raízes das montanhas, a terra de ferrolhos eternos, o sepulcro) reforçam a asfixia sentida por todo o ser vivo num meio privado de ar (Jn 2 3-6):

"Na minha afição invoquei o Senhor, e ele Ouviu-me. Clamei a Ti do meio da morada dos mortos, e Tu ouviste a minha voz. Lançastes-me ao abismo, ao seio dos mares e as correntes das águas envolveram-me. Todas as tuas vagas e todas as tuas ondas passaram por cima de mim. E eu já dizia: fui rejeitado diante dos teus olhos. Acaso me será dado ver ainda o teu santo templo? As águas me cercaram até ao pescoço, o abismo envolveu-me, as algas pegaram-se-me à cabeça; desci até às raízes das montanhas, até à terra cujos ferrolhos me prendem para sempre. Mas Tu, Senhor, meu Deus, salvaste a minha alma do sepulcro...”.

A travessia do Mar a pé enxuto pelos Hebreus liderados por Moisés constitui também um episódio em que as águas manifestam o seu poder letal contra os egípcios (Ex 14 21-29). Obedecendo a Deus e a Moisés, estas dividem-se criando terra seca, tal como acontecera na primeira e na segunda criação, para deixar passar os Hebreus e pô-los a salvo da perseguição dos exércitos. Ocorre portanto uma restauração temporária do momento crucial do Génesis, em que também se criam condições para a vida de alguns, até que as águas de novo se reúnem, aniquilando outros, neste caso os Egípcios ${ }^{23}$. Não se pode dizer que neste episódio as águas participem na destruição e no renascimento de uma nova criação da vida, tal como nos exemplos citados do Gen. Mas é um momento de renascimento e da confirmação da identidade deste povo que Deus decidira salvar no qual as águas domesticadas são instrumento de salvação e de aniquilação.

O cântico de júbilo de Moisés e da sua irmã, a profetiza Maria, (Ex 15), festejando a liberdade alcançada, reitera bastas vezes o motivo da água que mata, retomando o abismo, em contraposição com o motivo da água que salva os que devem ser resgatados, regressando à ordem da criação genesíaca ${ }^{24}$. Os gestos criadores e destruidores (o sopro de Deus, a Sua mão direita que se estende) são

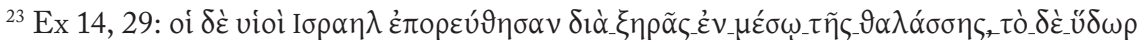

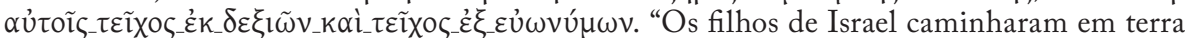
seca pelo meio do mar, e as águas eram para eles um muro à sua direita e à sua esquerda”.

${ }^{24}$ Ex 15, 1-21: 4 "Os carros de guerra do faraó e o seu exército ele atirou ao mar" (...) 5 cobrem-nos (Sept. ekalypse; Vulg.operuerunt) os abismos (Sept. Pontô; Vulg. abyssi); desceram às profundezas como uma pedra (...) $8 \mathrm{Com}$ o sopro das tuas narinas, as águas amontoaram-se (Sept. dieste; Vulg. congregatae sunt). As ondas ficaram paradas (Sept. epage; Vulg. stetit) como um muro, os abismos coalharam (Sept. epage; Vulg. congregata sunt) no coração do mar (...) 10 Sopraste com o teu vento e o mar os recobriu (Sept. ekalypse; Vulg. operuit): afundaram-se (Sept. edusan; Vulg. submersi sunt) como chumbo nas águas alterosas (...) 12 Estendeste a tua direita (...): a terra engoliu-os (Sept. katepien autous gế; Vulg. deuorauit eos terra) (...) $19 \mathrm{De}$ facto, os cavalos do faraó, com os seus carros de guerra e os seus cavaleiros, entraram no mar, e o Senhor fez voltar sobre eles (Sept. epegage;Vulg. reduxit) as águas do mar, mas os filhos de Israel caminharam em terra seca pelo meio do mar". 
convergentes, como se a criação e a destruição fossem realidades paralelas, mas invertidas, continuamente revisitadas.

A experiência do resgate das águas, que matam o que deve ser rejeitado e salvam os eleitos surge também revisitada nos episódios de batismo por imersão, tal como ele é descrito no NT, segundo um discurso e uma hermenêutica cristã que se apropria deste eixo de sentido do valor ambivalente das águas estruturado no AT. O batismo surge assim prefigurado nos episódios de afogamento de uns e de salvação de outros no AT, em que a água é, portanto, instrumento para uma teodiceia. No batismo, contudo, salvação e extermínio coexistem no mesmo indivíduo: extermina-se algo de um homem velho e faz-se renascer algo num homem novo, sendo a água, portanto, uma potência transformadora. Veja-se contudo que no AT, o eixo duplo da salvação e extermínio também se mantem quanto ao indivíduo, como o episódio de Moisés e de Jonas, já descritos, manifestam. A hermenêutica do batismo encontra-se sobejamente debatida pelos estudiosos e é demasiado vasta para a desenvolvermos com propriedade neste texto ${ }^{25}$, retendo nós apenas, sobre este domínio, o papel específico das águas na narrativa da ação de João Baptista e do batismo de Jesus (Mt 3,11; Mc 1, 4; 1 , 8; Lc 3, 16; Jo 1, 25-26). Em Marcos e em João, a experiência da imersão e do sair das águas de Jesus é tão significativa, que é ela que dá início aos Evangelhos, omitindo estes o nascimento e infância de Jesus que aparecem nos outros Evangelhos, como se Jesus nascesse, naquilo que importa, apenas nesta segunda vez. Em João, o relato permite o reconhecimento implícito de Cristo na pessoa de Jesus. Todos os outros Evangelhos, porém, associam este sair das águas a um reconhecimento externo, explícito (Mt; Mc; Lc) da filiação divina de Jesus e da sua identificação como o Messias. Outro aspeto de relevo nestas narrativas da ação de João Baptista e do batismo de Jesus está no facto de elas convergirem no consenso quanto ao ritual do batismo. João dá a este ritual um valor penitencial, capaz de transformar a natureza de quem o atravessa "eu batizo-vos em água para vos mover ao arrependimento". As palavras que João formula quanto ao significado do batismo focalizam-se na nova forma de batismo, pelo fogo e pelo Espírito Santo, que virá com o Messias. Esclarecido pela dimensão claramente penitencial, o batismo em água aparece formulado com referentes familiares, plausíveis para os judeus, mesmo para os mais conservadores da Lei (em Mateus, fariseus e saduceus). Quer-se com isto assinalar o significado do ritual do Baptista como um gesto que, sendo novo, se ancorava numa narrativa da história sagrada coerente com os valores que agora se revisitavam. A novidade está no valor penitencial do batismo e no anúncio da outra forma de batismo que virá, não no significado regenerador e criador da imersão na água e da emersão das águas, posto que este havia sido explorado nos passos do AT que destacámos.

\footnotetext{
${ }^{25}$ Scroggs 1973: 531-548.
} 
Das águas do Jordão emerge um homem novo, o filho de Deus, o que é claro em Marcos, que omite toda a vida de Jesus anterior ao batismo (Mc 1, 9-11). O discurso de João afirma que este é um batismo provisório, Cristo trará outro, em fogo e no Espírito Santo; Cristo emerge, para si (uma espécie de autoconsciência, ou de descoberta de si, o que é manifesto no Evangelho de João) e para os outros como um líder.

Esse poder destruidor e ao mesmo tempo renovador da água é lembrado na segunda Carta de Pedro, escrito anónimo já nos finais do séc. I, num momento em que se enfraquecem, ou são desacreditadas, as promessas escatológicas da segunda e definitiva vinda do Messias a inaugurar uma nova era: o tom deste discurso merece esta leitura: "para os que questionam a demora da destruição do velho mundo e a inauguração de um novo tempo, lembrem-se que já antes Deus criou terra seca a partir da confusão das águas, e, num tempo medido pela escala divina, os elementos do mundo se dissolverão de novo". Isto é, a vinda definitiva de Cristo insere-se no diálogo de criação e de destruição a partir das águas ${ }^{26}$.

Enquanto elemento destruidor e salvador, a água é o espaço da provação, do teste do qual se emerge transformado. Nos passos dos Evangelhos em que Jesus domina as águas e as criaturas que nele vivem, estas mantêm a ambivalência positiva e negativa, mas claramente probatória. A tempestade põe em perigo a barca onde estão os apóstolos, Jesus caminha sobre o mar para ir ter com eles. Ou seja, este é o Ser que "paira" sobre as águas, como o Deus criador do Génesis (Mt 14 22-33). Na narrativa de Mateus, os discípulos, assustados, não o reconhecem, e Pedro lança-lhe o desafio de provar a Sua identidade, pedindo-lhe que o faça caminhar sobre as águas. À ordem expressa de Jesus, Pedro dá uns passos mas, com medo do vento, afunda-se, pedindo a Jesus que o salve, o que acontece. Em Mt 8, 23-27, Mc 4, 35-41 e Lc 8, 22-25, temos uma variação de um acontecimento similar. Jesus está dentro da barca, adormecido, quando a tempestade ameaça afogar os discípulos. Não se fala da marcha sobre as águas, nem da

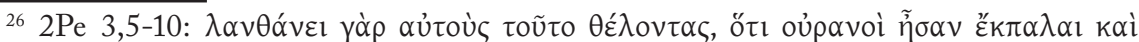

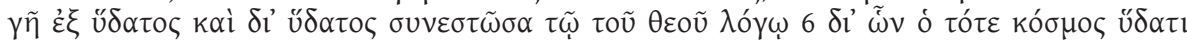

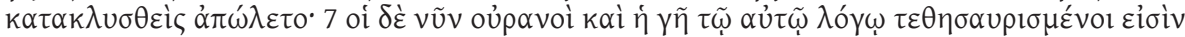

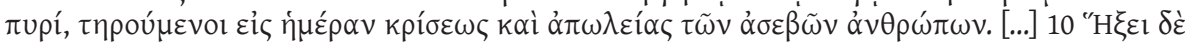

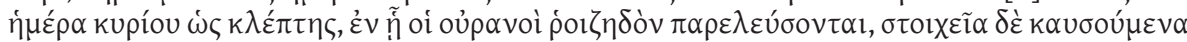

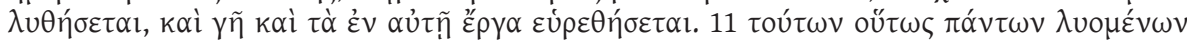

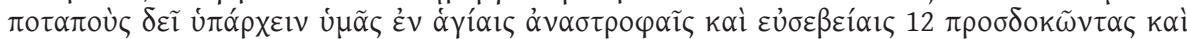

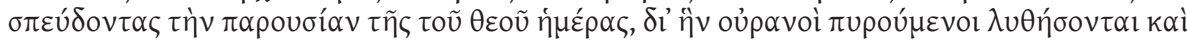

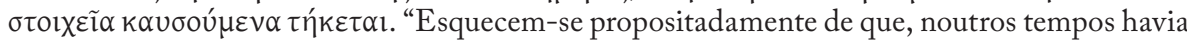
uns céus e uma terra que a palavra de Deus tornou firmes a partir das águas e no meio das águas; e, em virtude destas, o mundo de então pereceu afogado. Quanto aos céus e à terra que agora existem, a mesma palavra os tem reservado para o fogo, mantendo-os até ao dia do juízo e da perdição para os ímpios [...] Porém, o Dia do Senhor chegará como um ladrão: os céus desaparecerão com estrondo, os elementos do mundo abrasados dissolver-se-ão, assim como a terra e as obras que nela houver." 
iniciativa de Pedro, mas há três aspetos que aproximam estes dois esquemas narrativos: é um momento em que os apóstolos são postos à prova quanto à firmeza da sua fé (Pedro em Mt 14; todos os apóstolos nos restantes evangelhos) o que se associam ao seu receio do afogamento; Jesus exibe o poder de serenar o mar e a tempestade, e, em Mt 14, o poder de caminhar sobre as águas (tal como Deus antes da Criação, em Gen 1, 2). Por fim, as cenas terminam com a interrogação dos apóstolos sobre a identidade deste Homem a quem as águas obedecem e, em Mt 14, com a afirmação expressa da identidade de Jesus como filho de Deus. Na narrativa, esta certeza aparece justificada pela marcha sobre as águas e a salvação do apóstolo em perigo de afogamento.

Portanto, tal como o Pai Criador, o Filho de Deus é capaz de caminhar sobre as águas, dominá-las e resgatar da sua força destrutiva quem desejar, ou quem se mantiver fiel. Nestes passos a água como lugar de provação mantém-se no eixo de aniquilação e de salvação construído desde o Génesis. Mas traz com ela outra importante mensagem, que é a da confirmação de Cristo como Deus, proporcionando a identificação entre o Pai e o Filho, os dois ordenadores da água cósmica, chave de fé do cristianismo ${ }^{27}$.

Neste registo ambíguo, força de destruição mas também elemento que apaga, dissolve ou retém o mal nas suas profundezas, proporcionando a salvação do que merece ser salvo, permanece a água como elemento primordial que integra a ordem de Deus e que está a seu mando. Do batismo, Jesus emergiu para ser reconhecido explicitamente por Deus, ou por João, que deu testemunho, como Seu filho, com uma missão a cumprir; do batismo, também os homens reemergem limpos (lavados?) dos seus pecados. O abismo, ou as profundezas das águas, continuam pois a cumprir a sua função de encerrarem nelas o que deve ser encerrado, como o mal, os monstros que em circunstâncias de futuro previsível se libertam, como no Apocalipse ${ }^{28}$, ou os demónios, numa reposição da ordem. Assim se podem interpretar os episódios que surgem em Mc 5, 12-13; Lc 8, 22-37, em que os porcos possuídos pela legião de demónios se afogam; em Mt 4, 18-22; Mc 1, 18 o chamamento dos apóstolos, que em Lc 5, 1-11 se segue a um episódio de pescaria abundante; em Jo 21, 6-7, quando, após a ressurreição, Jesus volta a proporcionar uma pescaria abundante que conduz ao seu reconhecimento pelo apóstolo João. Este é Deus porque, como Ele, detém o poder de dominar as águas para além das limitações físicas e as criaturas que nela vivem. A imagem dos apóstolos tal como "pescadores de homens", alusiva à ideia da propagação da fé a um coletivo extenso (cf. a abundância da pescaria) também pode ser relacionada com a ideia da emersão do batismo: tal como os peixes pescados saem das águas pela ação do pescador, os homens são retirados das águas, onde

\footnotetext{
${ }^{27}$ Ramos 2008: 74, o poder demiúrgico do Filho.

${ }^{28}$ Ramos 1998: 30. Apoc. 13.
} 
se encontram inacessíveis, mortos para Deus (o Deus que paira sobre as águas não emerge delas), e são trazidos à vida, à terra seca, à salvação. As profundezas das águas, mortais para os seres da terra, servem de metáfora a que se associa o abismo, as trevas, a desordem anterior ao gesto criador de Deus.

Abandonando o plano narrativo, esse poder destruidor e simultaneamente renovador da água é lembrado na segunda Carta de Pedro, escrito anónimo já nos finais do séc. I, num momento em que se enfraquecem, ou são desacreditadas, as promessas escatológicas da segunda e definitiva vinda do messias a inaugurar uma nova era: o tom deste discurso merece esta leitura: "para os que questionam a demora da destruição do velho mundo e a inauguração de um novo tempo, lembrem-se que já antes Deus criou terra seca a partir da confusão das águas, e, num tempo medido pela escala divina, os elementos do mundo se dissolverão de novo". Isto é, a vinda de Cristo insere-se no ciclo cósmico de alternância entre a criação e a destruição a partir das águas ${ }^{29}$.

A $2 \mathrm{Pe}$ contém bons exemplos das primeiras exegeses tipológicas dos episódios do AT em que a água surge como espaço de provação, elemento de aniquilação para uns e de salvação para outros e em que esta leitura é integrada coerentemente na Revelação cristã, e utilizada para a reafirmação da constância dos planos de Deus entre os relatos do AT e do NT, num momento difícil e de dúvidas quanto à validade das promessas de Cristo. Dar sentido às mensagens da revelação passa por recuperar o seguro e não questionado património de sentidos legado pelos textos sagrados do judaísmo:

"4 Com efeito, se Deus não poupou aos anjos que pecaram e os precipitou nos abismos tenebrosos do inferno (...) 5 Se Deus não poupou o mundo antigo e só preservou oito pessoas, entre as quais Noé, quando desencadeou o dilúvio sobre o mundo dos ímpios (...) 9 é porque o Senhor sabe livrar os justos da provação e reservar os maus para o castigo...” (...) 17 Estes [sc. os maus) são fontes sem água e nuvens agitadas por turbilhões, destinados às profundezas das trevas (...)

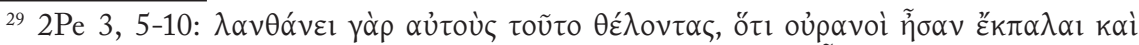

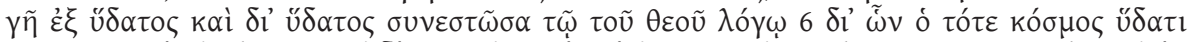

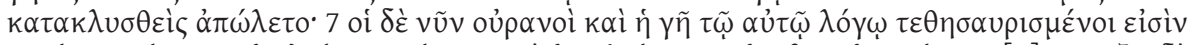

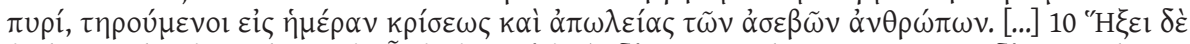

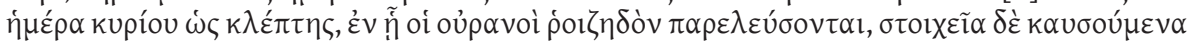

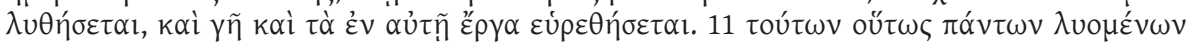

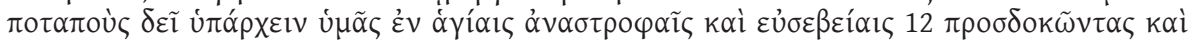

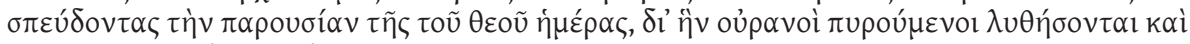

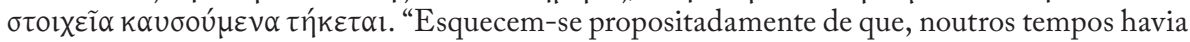
uns céus e uma terra que a palavra de Deus tornou firmes a partir das águas e no meio das águas; e, em virtude destas, o mundo de então pereceu afogado. Quanto aos céus e à terra que agora existem, a mesma palavra os tem reservado para o fogo, mantendo-os até ao dia do juízo e da perdição para os ímpios [...] Porém, o Dia do Senhor chegará como um ladrão: os céus desaparecerão com estrondo, os elementos do mundo abrasados dissolver-se-ão, assim como a terra e as obras que nela houver." 
esquecem-se, propositadamente que, desde há muito, existiam os céus e a terra, uma terra que, pela palavra de Deus, surgiu do seio da água e por meio da água (ek hydatos kai di' hydatos), 6 e que por estas mesmas causas, o mundo de então pereceu afogado (ho kosmos hydati kataklystheis apoleto). 7 Mas os céus e a terra que agora existem são guardados pela mesma palavra e reservados para o fogo no dia do Juízo e da perdição dos ímpios".

Redigida postumamente por alguém do círculo de Pedro, o final desta carta (2Pe 3, 15-16) aborda o conhecimento que os seus destinatários teriam já das cartas de Paulo e das "outras Escrituras", consideradas por Pedro como sendo difíceis de entender e de estarem a ser alvo de más interpretações e de deturpações. Não é irrelevante interrogarmo-nos sobre que textos são considerados aqui "outras escrituras". No entanto, estamos em crer que os que o autor tem em mente são os textos sagrados que aprendeu e conheceu enquanto Judeu, os seus mais familiares, ou seja, a tradição do AT. É irrelevante se ele conhece outros escritos neotestamentários que testemunham a revelação de Cristo, só especificando as cartas de Paulo, pois todos os episódios evocados para esclarecer as dificuldades na compreensão da fé existentes no presente do Autor pertencem ao património veterotestamentário. Exortando os cristãos a terem cautela quanto aos "falsos doutores" que corrompem a verdade, Pedro lembra os episódios atribulados de provação do passado para interpretar as dificuldades do presente e consolidar a fé nas profecias quanto ao fim dos tempos entre os cristãos que vacilavam. O estabelecimento deste diálogo entre os vários tempos valida um sentido coerente para os acontecimentos difíceis do presente da primeira geração apostólica e a evocação dos relatos veterotestamentários de aniquilação pela água, em que esta se valida como instrumento de uma teodiceia. Cria-se portanto um discurso que compreende o futuro a partir da narrativa da criação $(2 \mathrm{Pe} 3,5)$, um momento em que alguns foram resgatados e devolvidos a uma nova vida, e outros se perderam.

Numa breve conclusão, a ambivalência positiva e negativa das águas nos textos bíblicos encontra-se intrinsecamente relacionada com a experiência e a perceção do homem universal e do homem enquanto habitante do espaço concreto da geografia do mundo bíblico: a água é um elemento imprescindível à vida, à higiene, à saúde, aos demais usos do quotidiano e aceder a este recurso move, desde os primórdios, as civilizações. Portadora de vida, ela tem um potencial destruidor, quando escapa ao controlo e ocorrem inundações, quando se agita em tempestades. Mas também traz a morte quando, envenenada, mata os que dela precisam, ou quando afoga os que nela caem. Precisando de água e sendo sobretudo água, o ser humano como animal terrestre, não pode habitar as águas, em particular as suas profundezas sombrias e silenciosas. A par desta experiência real da água próxima e da água dos outros, ela própria ambivalente, tiveram inegável importância as culturas pré-clássicas de contacto com os Hebreus, as 
suas mitologias e as suas mitografias, que forneceram o esquema arquetípico relativo à água fundadora ${ }^{30}$. Estas perceções, pensamos nós, ajudaram a construir a complexidade do símbolo e das ocorrências da água nos textos bíblicos, em particular as que aqui nos ocuparam, as de manifesta ambivalência na classificação das águas, sejam estas um espaço a que os homens acedem mal (o mar, os espaços inundados), sejam estas recursos ou instrumentos materiais para as atividades e a vida humana (a água que lava, que sacia, que rega). Mas fundamental para a permanência coerente deste discurso foi a tradição literária, a revisitação interna e o diálogo intertextual entre os textos que viriam a constituir o corpus bíblico: vemos que o relato da criação do Génesis, a presença e o papel que nele exerce a água se propaga, diríamos que como um eco interdialogante, ao longo dos textos, garantindo uma unidade nesta avaliação ambígua da água.

\section{Bibliografia}

Alves, H. (coord.) (2012), Bíblia Sagrada, Difusora Bíblica.

Bienaimé, G. (1990), “L'annonce des fleuves d'eau vive en Jean 7, 37-39”, RTL 21.4: 417-454.

Colunga, A., Torrado, L. (1994) Biblia Vulgata. Madrid, Biblioteca de Autores Cristianos.

Combs, J., (2008) "A Ghost on the Water? Understanding an Absurdity in Mark 6:49-50", JBL 127.2: 345-358.

Danielou J., (1974) La Théologie du judéo christianisme, Desclée/Cerf, Paris.

Daniélou,J. (1946), “Traversée de la Mer Rouge et Baptême aux premiers siècles”, $R S c R$ 33: 402-30.

Daniélou, J. (1950), Sacramentum futuri: Études sur les origines de la typologie biblique. Paris, Beauchesne.

Daniélou, J. (1951), “Qu'est-ce que la typologie?” in L'Ancien Testament et les chrétiens, Auvray, P., et al. Eds, Paris, Cerf: 199-205.

Dias, P. B. (2010), "O peixe para os judeus e para os cristãos: leituras de um símbolo à luz da cultura greco-romana”, Humanitas 62: 147-163.

Dias P. B. (2011), "A Hispânia na Bíblia: Rom., 15; 1Mac.8”, Boletim de Estudos Clássicos 55: 45-53.

${ }^{30}$ Os artigos de Ramos 1998 e 2008, referidos na bibliografia, exploram o relevo do mar pré-clássico (i.e. das culturas sumérias e semíticas) na constituição da metaforicidade das águas na literatura bíblica. 
Dias P. B. (2015) "A serpente tartaruga: o testemunho de O Fisiólogo acerca dos monstros marinhos e da baleia", Cadmo 24: 123-142.

Goppelt, L. (1982), Typos. The Typological Interpretation of the Old Testament in the New. Eerdmans, Grand Rapids: 179-97.

Hanson R. P. C. (2002), Allegory and Event: A Study of the Sources and Significance of Origen's Interpretation of Scripture. Westminster John Knox.

Heil, J. P., (1981) "Jesus Walking on the Sea: Meaning and Gospel Functions of Matt. 14:22 23, Mark 6:45-52 and John 6:15b-21”, AnBib 87, Rome, Biblical Institute Press.

Isbouts, J.-P. (2007) The Biblical World: An Illustrated Atlas U.S. National Geographic Society.

Lambert, W. G., Millard, A. R. (1999). Atrahasis: The Babylonian Story of the Flood. Eisenbrauns.

Lampe, G. W.H., Woollcombe, K.J.(1957), Essays on Typology. London, SCM Press. Marcus, J. "Rivers of Living Water from Jesus' Belly (John 7:38)", JBL 117. 2: 328.

Martens P. (2008), "Revisiting the Allegory/ Typology distinction: The case of Origen", Journal of Early Christian Studies 16. 3: 283-317.

Nestle,E.,Aland,B.(1993), Nouum Testamentum Graece,Deustsche Bibelgesellchaft.

Porter, Stanley E. (1997), "The Use of the OT in the NT: A Brief Comment on Method and Terminology," in Evans, C. A., Sanders J. A. eds., Early Christian Interpretation of the Scriptures of Israel: Investigations and Proposals. Sheffield, Sheffield Academic Press.

Rahlfs, A. (2004), Septuaginta. Deustsche Bibelgesellchaft.

Ramos, J. A. (1998) “Biblicamente, o mar”, Revista da Faculdade de Letras 23: 13-35.

Ramos,J.A.(2008), "Metaforicidade humana do mar pré-clássico”, Cadmo 18:53-80.

Scroggs, R. Groff K. (1973) "Baptism in Mark: Dying and Rising with Christ" JBL 92.4: 531-548.

Tigay, J. H. (1982), The Evolution of the Gilgamesh Epic. Filadelfiam, University of Pennsylvania Press.

Van Dorn, D. (2009), Waters of Creation. A Biblical Theological Study of Baptism. Colorado, Waters of Creation Publishing.

Wright, G. E, (1945) The Westminster historical atlas to the Bible. Philadelphia, Westminster Press. 